\title{
CALCIUM EXCHANGE OF THE INTESTINE IN EXPERIMENTAL HYPERTHYROIDISM ${ }^{1,2}$
}

\author{
By T. L. ALTHAUSEN, WM. J. KERR AND M. STOCKHOLM \\ (From the Department of Medicine, University of California Medical School, San Francisco)
}

(Received for publication July 31, 1939)

The work of Parhon (1) and of Aub, Bauer, Heath and Ropes (2) established the existence of a negative calcium balance in experimental and in clinical hyperthyroidism. Pugsley and Anderson $(3,4)$ and Cope and Donaldson (5) among others confirmed this finding in rats and in human beings, respectively, and in addition, in agreement with Aub (6), stressed the prominent part which loss of calcium in the feces plays in hyperthyroidism, in contrast to other diseases characterized by a negative calcium balance. Hansman and Wilson (7) and Hansman and Fraser (8) recently showed that occasionally calcium equilibrium may be present in clinical hyperthyroidism, and that the intestine need not always be the principal route of excretion of calcium.

Kummer (9) suggested that diminished absorption of dietary calcium accounted for the high calcium content of feces in patients with hyperthyroidism. On the other hand, Aub et al. (2) demonstrated the occurrence of osteoporosis in patients with hyperthyroidism and obtained data on the simultaneous increase in excretion of phosphorus which " was quantitatively such as to suggest that most of the calcium excreted came from tertiary calcium phosphate in the bones." This and certain negative data influenced Albright, Bauer and Aub (10) to postulate that the thyroid hormone exerts a specific catabolic action on the metabolism of calcium phosphate in bones. Recently the possibility that in hyperthyroidism there may be an " inability to assimilate the calcium of the food quite apart from the mobilization of calcium from the bones" was again brought up by Hansman and Fraser (8).

Most investigators in this field were chiefly interested in the endogenous metabolism of calcium, and conducted their studies with diets very low

1 Aided by a grant from the Christine Breon Fund for Medical Research.

${ }^{2}$ Read before the Annual Meeting of the American Association for the Study of Goiter at Cincinnati, May 22 to $24,1939$. in calcium in order to eliminate the factor of unabsorbed dietary calcium. However, this experimental arrangement does not distinguish between increased excretion of calcium into the intestine and decreased re-absorption of excreted calcium. Also, apparently no attempts have been made to study quantitatively whether diminished absorption of calcium from the food could be a factor contributing to the loss of calcium from the body in hyperthyroidism. The latter possibility presented itself prominently when we discovered that intestinal absorption of carbohydrates and of fatty acids was greatly increased in hyperthyroidism (11), suggesting that absorption of calcium may be decreased in this disease through preferential absorption of other food elements.

For these reasons, we undertook to study intestinal absorption and excretion of calcium in normal and in hyperthyroid rats. An additional incentive for this study was furnished by a suggestion of Albright et al. (10), based on the work of Petersen and Levinson (12) that increased tissue permeability might be the cause of increased calcium excretion. If increased permeability of the intestinal mucosa were the cause of increased diffusion of calcium from the blood into the intestine, one would expect to find also an abnormally high rate of diffusion of calcium in the reverse direction, provided that its concentration in the intestine exceeded that in the blood.

Just this was reported by Guassardo and Peola (13) who studied the absorption of calcium chloride from an isotonic solution by means of a double Vella fistula in 2 dogs before and after administration of thyroxin. In three control experiments, each lasting 30 minutes, their dogs absorbed on the average 39 and 37 per cent of the calcium introduced into the intestinal loop. In two similar experiments on each dog performed 20 minutes after intravenous injection of $1.1 \mathrm{mgm}$. of thyroxin (the dogs weighed about $4.5 \mathrm{kgm}$.), they absorbed on the average 59 and 60 per cent, respectively, of the introduced calcium. 
TABLE I

Absorption of calcium in normal rats during fasting

\begin{tabular}{|c|c|c|c|c|c|c|c|c|c|c|c|}
\hline \multirow{2}{*}{$\begin{array}{c}\text { Number } \\
\text { of } \\
\text { rats }\end{array}$} & \multirow{2}{*}{$\begin{array}{c}\text { Range of } \\
\text { original } \\
\text { weight }\end{array}$} & \multirow{2}{*}{$\begin{array}{c}\text { Loss of } \\
\text { weight } \\
\text { after } \\
\text { fasting } \\
24 \text { hours }\end{array}$} & \multirow{2}{*}{$\begin{array}{l}\text { Dose of } \\
\text { calcium } \\
\text { per } 100 \\
\text { grams of } \\
\text { weight }\end{array}$} & \multicolumn{2}{|c|}{$\begin{array}{l}\text { Amount of calcium } \\
\text { absorbed in } 6 \text { hours }\end{array}$} & \multirow{2}{*}{$\begin{array}{c}\text { Number } \\
\text { of } \\
\text { rats }\end{array}$} & \multirow{2}{*}{$\begin{array}{c}\text { Range of } \\
\text { original } \\
\text { weight }\end{array}$} & \multirow{2}{*}{$\begin{array}{c}\text { Loss of } \\
\text { weight } \\
\text { after } \\
\text { fasting } \\
24 \text { hours }\end{array}$} & \multirow{2}{*}{$\begin{array}{c}\text { Dose of } \\
\text { calcium } \\
\text { per } 100 \\
\text { grams of } \\
\text { weight }\end{array}$} & \multicolumn{2}{|c|}{$\begin{array}{l}\text { Amount of calcium } \\
\text { absorbed in } 18 \text { hours }\end{array}$} \\
\hline & & & & $\begin{array}{l}\text { Per } 100 \text { grams } \\
\text { of weight }\end{array}$ & $\begin{array}{c}\text { Per } \\
\text { cent }\end{array}$ & & & & & $\begin{array}{c}\text { Per } 100 \text { grams } \\
\text { of weight }\end{array}$ & $\begin{array}{l}\text { Per } \\
\text { cent }\end{array}$ \\
\hline 6 & $\begin{array}{c}\text { grams } \\
160-200\end{array}$ & $\begin{array}{c}\text { per cent } \\
5.2\end{array}$ & $\begin{array}{l}m g m . \\
14.79\end{array}$ & $\begin{array}{c}m g m . \\
6.01 \pm 1.23^{*}\end{array}$ & 40 & & grams & per cent & $m g m$. & $m g m$. & \\
\hline 11 & $168-208$ & 6.5 & 21.35 & $9.61 \pm 0.96$ & 45 & 4 & $138-160$ & 6.2 & 18.37 & $13.91 \pm 1.34^{*}$ & 77 \\
\hline \multirow[t]{2}{*}{10} & $150-180$ & 7.6 & 26.44 & $15.02 \pm 2.08$ & 58 & 3 & $155-176$ & 7.7 & 23.60 & $17.19 \pm 0.99$ & 72 \\
\hline & & & & & & 3 & $165-174$ & 7.1 & 35.78 & $30.26 \pm 3.27$ & 84 \\
\hline
\end{tabular}

* Standard deviation.

\section{EXPERIMENTS}

\section{Intestinal absorption of calcium}

a. Absorption during fasting. After being fasted in a metabolic cage for 24 hours in order to clear the intestine of food residues, young rats were given by stomach-tube several measured amounts of a 10 per cent solution of calcium lactate. After 6 hours in some cases, and 18 hours in others, the animals were sacrificed, and the contents of the entire digestive tract were used for determinations of residual calcium. Figures for absorption of calcium by normal rats are given in Table I. In this table it is seen that the absorption of calcium under our experimental conditions was approximately proportional to the dose of calcium lactate, and that its rate increased somewhat with the size of the dose. On the other hand, extension of the time allowed for absorp- tion of a given amount of calcium lactate from 6 to 18 hours resulted in comparatively little additional absorption, so that about 20 per cent of the administered calcium still remained in the digestive tract at the end of 18 hours. A similar observation was made by Cohn and Greenberg (14) in regard to the absorption of phosphorus.

A number of rats were rendered hyperthyroid by intraperitoneal injections of $0.1 \mathrm{mgm}$. of thyroxin per 100 grams of body weight given daily for 12 days. The average basal metabolic rate of rats so treated, as determined in a closed circuit apparatus similar to that used by Benedict and Macleod (15), is increased about 50 per cent. These rats were then used for the absorption experiment as described.

Table II gives figures for the absorption of calcium by the hyperthyroid rats and by the corresponding controls for each dose of calcium lac-

TABLE II

Absorption of calcium in normal and in hyperthyroid rats during fasting and on a calcium-free diet

\begin{tabular}{|c|c|c|c|c|c|c|c|c|c|c|c|}
\hline \multirow[b]{2}{*}{$\begin{array}{c}\text { Dietary } \\
\text { status }\end{array}$} & \multirow[b]{2}{*}{$\begin{array}{l}\text { Ab- } \\
\text { sorp- } \\
\text { tion } \\
\text { time }\end{array}$} & \multicolumn{5}{|c|}{ Normal rats } & \multicolumn{5}{|c|}{ Hyperthyroid rats } \\
\hline & & $\begin{array}{c}\text { Num- } \\
\text { ber } \\
\text { of } \\
\text { rats }\end{array}$ & $\begin{array}{l}\text { Range of } \\
\text { original } \\
\text { weight }\end{array}$ & $\begin{array}{c}\text { Loss of } \\
\text { weight } \\
\text { after } \\
\text { fasting } \\
24 \text { hours }\end{array}$ & $\begin{array}{c}\text { Dose } \\
\text { of } \\
\text { calcium }\end{array}$ & $\begin{array}{l}\text { Calcium ab- } \\
\text { sorbed per 100 } \\
\text { grams of weight }\end{array}$ & $\begin{array}{c}\text { Num- } \\
\text { ber } \\
\text { of } \\
\text { rats }\end{array}$ & $\begin{array}{c}\text { Range of } \\
\text { original } \\
\text { weight }\end{array}$ & $\begin{array}{c}\text { Loss of } \\
\text { weight } \\
\text { after } \\
\text { fasting } \\
24 \text { hours }\end{array}$ & $\begin{array}{c}\text { Dose } \\
\text { of } \\
\text { calcium }\end{array}$ & $\begin{array}{l}\text { Calcium ab- } \\
\text { sorbed per } 100 \\
\text { grams of weight }\end{array}$ \\
\hline \multirow{3}{*}{ Fasting } & $\begin{array}{c}\text { hours } \\
6\end{array}$ & 11 & $\begin{array}{c}\text { grams } \\
168-208\end{array}$ & $\begin{array}{c}\text { per cent } \\
6.5\end{array}$ & $\begin{array}{c}m g m . \\
21.35\end{array}$ & $\begin{array}{c}\text { mgm. } \\
9.61 \pm 0.96^{*}\end{array}$ & 10 & $\begin{array}{c}\text { grams } \\
178-228\end{array}$ & $\begin{array}{c}\text { per cent } \\
14.6\end{array}$ & $\begin{array}{l}m g m . \\
21.00\end{array}$ & $\underset{11.13 \pm 0.39 *}{m g m .}$ \\
\hline & 6 & 10 & $150-180$ & 7.6 & 26.44 & $15.02 \pm 2.08$ & 12 & $160-192$ & 14.9 & 27.71 & $16.29 \pm 1.49$ \\
\hline & 18 & 3 & $165-174$ & 7.1 & 36.78 & $30.26 \pm 3.27$ & 4 & $208-260$ & 13.9 & 33.22 & $29.61 \pm 1.15$ \\
\hline $\begin{array}{l}\text { Calcium-free } \\
\text { diet }\end{array}$ & 6 & 8 & $160-210$ & 0.0 & 21.14 & $8.58 \pm 1.07$ & 10 & $200-232$ & 8.9 & 22.46 & $8.89 \pm 1.29$ \\
\hline
\end{tabular}

* Standard deviation. 
tate. From a comparison of these figures it can be concluded that hyperthyroidism does not materially affect the intestinal absorption of calcium in fasting rats when an excess of calcium lactate is present.

b. Absorption on a calcium-free diet. In this experiment, normal and hyperthyroid rats were fed on a calcium-free diet adequate in other respects and containing 26 per cent of fat for 2 days before the absorption experiment. They were not fasted, and had access to food throughout the absorption experiment. Figures for absorption of calcium in both groups of rats fed on the calciumfree diet were very similar, and are given in Table II. From a comparison of these figures with those obtained from fasting rats that received the same dose of calcium lactate, it is seen that the presence of food does not significantly decrease the absorption of calcium in either normal or hyperthyroid rats when an excess of calcium lactate is present in the intestine.

Since rats feed chiefly during the night, while our absorption experiments were started in the morning and carried out during the day, it was thought that the small decrease in absorption of calcium seen in fed as compared to fasting hyperthyroid rats might be rendered significant by simultaneously administering some food. Accordingly, the calcium lactate was given to 6 hyperthyroid rats in a 20 per cent solution of dextrose without altering the absorption of calcium.

c. The effect of phlorizin on absorption. It has been suggested by Verzár and McDougal (16) that the formation of calcium-phosphorus compounds in the intestinal mucosa may play a part in the absorption of calcium. In view of our previous finding that phosphorylation in the in- testine is altered in hyperthyroidism, it seemed of interest to learn whether inhibition of intestinal phosphorylation would affect the absorption of calcium. For this purpose normal rats were given two different amounts of calcium lactate with $50 \mathrm{mgm}$. of phlorizin in the solution. The figures in Table III show that administration of phlorizin did not affect the absorption of calcium.

\section{Intestinal excretion of calcium}

a. Excretion during fasting. Young normal and hyperthyroid rats were fasted in a metabolic cage for 30 hours before determinations of calcium in the washings from the entire gastro-intestinal tract were made. The figures for the amount of calcium present in the digestive tract of these rats are given in Table IV. From these figures it is clear that the intestine of hyperthyroid rats contained no more excreted calcium than that of normal rats.

b. Excretion on a calcium-free diet. In this experiment, the rats were fed a calcium-free diet as mentioned previously. Determinations of calcium in the contents of the entire digestive tract were made, and are recorded in Table IV. From these figures, it is seen that the presence of food increased the amounts of excreted calcium in the intestines of both normal and hyperthyroid rats. This was somewhat more marked in the hyperthyroid group.

With the object of possibly intensifying this finding by more prolonged administration of thyroxin, determinations of excreted calcium into the intestine were performed in 8 rats injected with thyroxin for 3 weeks, and in 4 rats similarly treated for 1 month instead of for 12 days. The severity of hyperthyroidism in the last group of

TABLE III

Effect of phlorizin on absorption of calcium

\begin{tabular}{|c|c|c|c|c|c|c|c|c|c|}
\hline \multicolumn{5}{|c|}{ Normal rats } & \multicolumn{5}{|c|}{ Rats treated with phlorixin } \\
\hline $\begin{array}{c}\text { Number } \\
\text { of } \\
\text { rats }\end{array}$ & $\begin{array}{l}\text { Range of } \\
\text { original } \\
\text { weight }\end{array}$ & $\begin{array}{l}\text { Loss of } \\
\text { weight } \\
\text { after } \\
\text { fasting } \\
24 \text { hours }\end{array}$ & $\begin{array}{c}\text { Dose of } \\
\text { calcium } \\
\text { per 100 } \\
\text { grams of } \\
\text { weight }\end{array}$ & $\begin{array}{l}\text { Amount of } \\
\text { calcium } \\
\text { absorbed } \\
\text { per } 100 \text { grams } \\
\text { of weight }\end{array}$ & $\begin{array}{c}\text { Number } \\
\text { of } \\
\text { rats }\end{array}$ & $\begin{array}{l}\text { Range of } \\
\text { original } \\
\text { weight }\end{array}$ & $\begin{array}{l}\text { Loss of } \\
\text { weight } \\
\text { after } \\
\text { fasting } \\
24 \text { hours }\end{array}$ & $\begin{array}{l}\text { Dose of } \\
\text { calcium } \\
\text { per } 100 \\
\text { grams of } \\
\text { weight }\end{array}$ & $\begin{array}{l}\text { Amount of } \\
\text { calcium } \\
\text { absorbed } \\
\text { per } 100 \text { grams } \\
\text { of weight }\end{array}$ \\
\hline 11 & $\begin{array}{c}\text { grams } \\
168-208\end{array}$ & $\begin{array}{c}\text { per cent } \\
6.5\end{array}$ & $\begin{array}{l}m g m \\
21.35\end{array}$ & $\begin{array}{c}\text { mgm. } \\
9.61 \pm 0.96^{*}\end{array}$ & 3 & $\begin{array}{c}\text { grams } \\
200-208\end{array}$ & $\begin{array}{l}\text { per cent } \\
8.5\end{array}$ & $\begin{array}{l}\text { mgm. } \\
21.95\end{array}$ & $\begin{array}{c}\text { mgm. } \\
10.61 \pm 0.02\end{array}$ \\
\hline 10 & $150-180$ & 7.6 & 26.44 & $15.02 \pm 2.08$ & 3 & $180-208$ & 2.9 & 28.28 & $14.57 \pm 2.82$ \\
\hline
\end{tabular}

* Standard deviation. 
TABLE IV

Intestinal excretion of calcium in normal and in hyperthyroid rats during fasting and on a calcium-free diet

\begin{tabular}{|c|c|c|c|c|c|c|c|c|}
\hline \multirow[b]{2}{*}{ Dietary status } & \multicolumn{4}{|c|}{ Normal rats } & \multicolumn{4}{|c|}{ Hyperthyroid rats } \\
\hline & $\begin{array}{c}\text { Number } \\
\text { of } \\
\text { rats }\end{array}$ & $\begin{array}{l}\text { Range of } \\
\text { original } \\
\text { weight }\end{array}$ & $\begin{array}{c}\text { Loss of } \\
\text { weight } \\
\text { after } \\
\text { fasting } \\
30 \text { hours }\end{array}$ & $\begin{array}{l}\text { Amount of } \\
\text { calcium } \\
\text { found } \\
\text { in the } \\
\text { intestine }\end{array}$ & $\begin{array}{c}\text { Number } \\
\text { of } \\
\text { rats }\end{array}$ & $\begin{array}{l}\text { Range of } \\
\text { original } \\
\text { weight }\end{array}$ & $\begin{array}{l}\text { Loss of } \\
\text { weight } \\
\text { after } \\
\text { fasting } \\
30 \text { hours }\end{array}$ & $\begin{array}{l}\text { Amount of } \\
\text { calcium } \\
\text { found } \\
\text { in the } \\
\text { intestine }\end{array}$ \\
\hline Fasting . . . . . . & 10 & $\begin{array}{c}\text { grams } \\
160-212\end{array}$ & $\begin{array}{c}\text { per cent } \\
7.9\end{array}$ & $\begin{array}{c}\text { mgm. } \\
2.36 \pm 0.5\end{array}$ & 10 & $\begin{array}{c}\text { grams } \\
165-200\end{array}$ & $\begin{array}{c}\text { per cent } \\
15.5\end{array}$ & $\underset{1.95 \pm 0.46}{m g m .}$ \\
\hline Calcium-free diet.... & 10 & $170-230$ & 0.0 & $3.94 \pm 0.28$ & 20 & $200-313$ & 10.2 & $4.69 \pm 0.74$ \\
\hline
\end{tabular}

* Standard deviation.

animals is shown by the fact that 5 out of 9 rats died from hyperthyroidism before the end of the month. However, the amounts of calcium found in their intestines were practically the same as those in rats treated with thyroxin for the usual 12 days. For this reason, in Table IV the figures for all fed hyperthyroid rats were combined.

\section{Fecal excretion of calcium}

a. The influence of thyroxin. The calcium content of feces was determined over 2-day periods in rats receiving our calcium-free diet for 3 and for 10 days, respectively, previous to collection, before and after 3 weeks of injections with thyroxin. Figures for the average daily fecal output of calcium under these conditions are given in Table V. These figures show that the fecal output of calcium of rats deprived of calcium for 3 days was more than twice that of rats that were on a calcium-free diet for 10 days, and that administration of thyroxin increased fecal excretion of calcium 98 and 100 per cent, respectively, in the two groups.

b. The rôle of increased food intake. Since our hyperthyroid rats ate about twice the normal amount of food ( 8 grams per 100 grams of weight as against a normal of 4 grams), it was felt that the greater volume of food passing through their digestive tracts might be a factor in decreasing re-absorption of calcium excreted into the intes-

TABLE V

Influence of thyroxin, of food intake, and of intestinal peristalsis on fecal excretion of calcium

\begin{tabular}{|c|c|c|c|c|c|c|c|}
\hline \multirow{2}{*}{ Thyroid status } & \multirow{2}{*}{$\begin{array}{l}\text { Experimental } \\
\text { condition }\end{array}$} & \multicolumn{3}{|c|}{$\begin{array}{l}\text { Rats deprived of calcium for } 3 \text { days } \\
\text { before stool collection }\end{array}$} & \multicolumn{3}{|c|}{$\begin{array}{l}\text { Rats deprived of calcium for } 10 \text { days } \\
\text { before stool collection }\end{array}$} \\
\hline & & $\begin{array}{l}\text { Number } \\
\text { of rats }\end{array}$ & $\begin{array}{c}\text { Range of } \\
\text { weight }\end{array}$ & $\begin{array}{l}\text { Daily fecal } \\
\text { calcium }\end{array}$ & $\begin{array}{l}\text { Number } \\
\text { of rats }\end{array}$ & $\begin{array}{c}\text { Range of } \\
\text { weight }\end{array}$ & $\begin{array}{l}\text { Daily fecal } \\
\text { calcium }\end{array}$ \\
\hline Normal........ & $\begin{array}{l}\text { Food intake } \\
4 \text { grams* }\end{array}$ & 10 & $\begin{array}{c}\text { grams } \\
185-231\end{array}$ & $\begin{array}{c}m g m . \\
4.47 \pm 0.52 \dagger\end{array}$ & 4 & $\begin{array}{c}\text { grams } \\
220-275\end{array}$ & $\begin{array}{l}m g m . \\
2.04\end{array}$ \\
\hline Hyperthyroid.... & $\begin{array}{l}\text { Food intake } \\
8 \text { grams* }\end{array}$ & 10 & $187-227$ & $8.85 \pm 1.26$ & 4 & $220-275$ & 4.09 \\
\hline Hyperthyroid.... & $\begin{array}{l}\text { Food intake } \\
4 \text { grams* }\end{array}$ & 10 & $190-222$ & $5.79 \pm 0.35$ & & & \\
\hline Normal........ & $\begin{array}{l}\text { Administration } \\
\text { of castor oil }\end{array}$ & 10 & $193-230$ & $7.77 \pm 0.99$ & 4 & $180-211$ & 4.01 \\
\hline Normal......... & $\begin{array}{l}\text { Administration } \\
\text { of cascara }\end{array}$ & 10 & $187-245$ & $7.86 \pm 0.74$ & & & \\
\hline$\overline{\text { Hyperthyroid.... }}$ & $\begin{array}{l}\text { Administration } \\
\text { of morphine }\end{array}$ & 10 & $185-240$ & $5.51 \pm 0.38$ & & & \\
\hline
\end{tabular}

- Per 100 grams of weight.

$\uparrow$ Standard deviation 
tine. For this reason, the fecal excretion of calcium was determined in hyperthyroid rats over a 2-day period while the animals were limited to a daily ration of 4 grams of the calcium-free food mixture.

In Table $\mathrm{V}$ it is seen that hyperthyroid rats on a restricted food intake excreted in the feces 35 per cent less calcium than the hyperthyroid rats on an unlimited diet, but 29 per cent more calcium than the normal animals.

c. The effect of increased intestinal peristalsis. In order to investigate the effect of increased intestinal peristalsis on excretion of calcium in the feces, two experiments were performed:

(1) The fecal calcium was determined over a 2-day period in normal rats which were kept on a calcium-free diet for 3 days and received by mouth twice a day 2 drops of castor oil, or 5 drops of fluid-extract of cascara. These amounts of castor oil or of cascara were not sufficient to produce diarrhea in any of the animals. As seen in Table $\mathrm{V}$, the fecal excretion of calcium rose 74 and 76 per cent, respectively, under the influence of these drugs, and almost equalled that of hyperthyroid rats. In rats deprived of calcium for 10 days, the fecal calcium was increased 96 per cent by ingestion of castor oil. Administration of castor oil to hyperthyroid rats produced no appreciable increase in fecal calcium.

(2) The fecal calcium was determined over a period of 2 days in hyperthyroid rats on a calciumfree diet whose intestinal peristalsis was slowed by two intraperitoneal injections of $0.25 \mathrm{mgm}$. of morphine sulphate a day. From Table V it is seen that the fecal excretion of calcium in these rats was decreased 38 per cent.

\section{Immediate effect of intravenously injected thy- roxin on absorption of dextrose}

In order to test whether intravenously injected thyroxin is capable of exerting its physiological action on absorption in the time allotted by Guassardo and Peola, the following experiment was performed. Five male rats fasted for 24 hours were anesthetized with ether for the few minutes necessary to dissect the jugular vein and inject $0.1 \mathrm{mgm}$. of crystalline thyroxin in $1 \mathrm{cc}$. of physiological saline solution. Twenty minutes later, 300 mgm. of dextrose per 100 grams of weight were administered by stomach-tube in the form of a 20 per cent solution. After allowing an hour for absorption, the unabsorbed residue of dextrose in the digestive tract was determined. As a control, 4 more rats were subjected to the same procedure except that physiological saline solution was injected in place of thyroxin. The control animals absorbed $128 \pm 37 \mathrm{mgm}$. and the rats injected with thyroxin absorbed $119 \pm 23 \mathrm{mgm}$. of dextrose per 100 grams of weight. From these figures it is seen that in rats intravenously injected, thyroxin has no effect on the absorption of dextrose for at least 1 hour and 20 minutes, which is 30 minutes longer than the time allowed by the Italian workers.

\section{COMMENTS}

Failure of the fasting hyperthyroid rats to absorb more calcium from an excess of calcium lactate than was done by the corresponding controls indicates that there is no increase in permeability of the intestinal mucosa in hyperthyroidism. Additional evidence that hyperthyroidism has no influence on simple diffusion through the intestinal mucosa is seen in our previous experiment with xylose, the absorption of which was not increased in this condition after abnormally rapid emptying of the stomach was controlled with benzedrine (11). Consequently, increased permeability can no longer be considered among the possible factors causing loss of calcium in the feces of hyperthyroid animals.

Several doses of calcium lactate and two different periods of absorption were used in this experiment to rule out the possibility that, with any one dose or time interval, rapid excretion of newly absorbed calcium could have masked increased absorption of calcium.

We are inclined to ascribe the increased $a b-$ sorption of calcium from the intestinal loop of the dog reported by Guassardo and Peola to some factor other than the action of thyroxin, because in repeating their experiment with rats, we were unable to demonstrate any action of intravenously injected thyroxin on the very sensitive mechanism of intestinal absorption of dextrose, in spite of the fact that we doubled the time which these workers allowed for their absorption experiment.

The possibility that the absorption and excre- 
tion of calcium are determined not alone by laws of simple diffusion, if phosphorylation plays any rôle in its passage through the intestinal mucosa, was ruled out by the experiment in which phlorizin was used to inhibit intestinal phosphorylation without any change in the amount of absorbed calcium. Incidentally, this experiment also proves conclusively that phlorizin has no depressing effect on intestinal absorption in general.

The fact that the absorption of calcium lactate was not diminished in fed hyperthyroid rats indicates that no impairment in the intestinal absorption of dietary calcium exists in experimental hyperthyroidism due to increased absorption of competing foodstuffs or any other cause, provided that an abundance of calcium is present in the intestine.

Turning to the question of intestinal excretion of calcium, we must consider the mechanism of intestinal absorption. According to Verzár and McDougal (16), the present conception of intestinal absorption by simple diffusion is that, during passage through the small intestine, the ions present in its contents and those found in the blood plasma reach an equilibrium due to a twoway exchange of electrolytes between the lumen of the intestine and the capillaries. When the fluid contents of the small intestine enter the colon, they are subjected to hydrostatic pressure which forces part of the water into the capillaries, rendering the remaining mixture hypertonic. This causes the diffusion of more electrolytes into the blood. The indicated process goes on until the food residues assume a solid consistency and are expelled as feces with little loss of valuable salts from the body. This conception in application to the calcium exchange of the intestine is supported by the finding that, contrary to the opinion of earlier authors, no calcium is excreted into the colon $(17,18)$.

In the light of this conception, we would expect increased diffusion of calcium from the blood into the small intestine only when the calcium level of the blood is increased. This is found in hyperthyroidism only to a slight degree or not at all $(2,6)$, and therefore can hardly be a major factor in the loss of calcium through the bowel, especially since in hyperparathyroidism, where the blood calcium is definitely elevated, there is no excessive excretion of calcium in the feces. On the other hand, the fact that there is no active excretion of calcium into the intestine in hyperthyroidism, over that expected through normal diffusion from the blood, is demonstrated by the equal amounts of calcium found in the intestine of fasting normal and hyperthyroid rats. It is in these animals that one would expect to obtain the greatest difference in this respect if active excretion were taking place, because fasting has an inhibiting influence on peristalsis which is more active in hyperthyroidism, and therefore in fed rats would tend to minimize the difference by sweeping out some of the extra calcium.

There remain two explanations for the increased fecal output of calcium in hyperthyroidism. The first of these is that the approximately double amount of food passing through the digestive tract of hyperthyroid rats may interfere with normal re-absorption of excreted calcium. This possibility was sugested by our finding that both normal and hyperthyroid rats maintained on a calcium-free diet had more calcium in their intestinal contents than the fasting animals, and that this finding was more marked in hyperthyroid rats. The experiment in which the food of hyperthyroid rats was limited to the amount usually consumed by normal animals shows that on a calcium-free diet an increased intake of food plays a definite part in the loss of calcium through the bowel, although it does not account for all of it.

The second explanation is that increased intestinal peristalsis accelerates the passage of feces through the colon to such an extent as to interfere with normal re-absorption of excreted calcium. This possibility was suggested by the fact that the fecal excretion of calcium by hyperthyroid rats is markedly increased without a corresponding increase in the calcium content of the intestine. Our experiments with administration of subpurgative doses of castor oil or of cascara to normal rats at two levels of fecal excretion of calcium $^{3}$ show that the endogenous calcium in the feces is markedly raised by intestinal hyperperistalsis, and that this factor alone could account for the total increase of fecal calcium in hyperthyroidism. That peristalsis actually does play an

\footnotetext{
3 Following deprivation of calcium for 3 and for 10 days, respectively. (See Table V.)
} 
important part in the increased fecal excretion of calcium by hyperthyroid rats was demonstrated by our experiment in which slowing of intestinal peristalsis with morphine markedly reduced the calcium content of the feces in such animals.

The presence of increased intestinal peristalsis in patients with hyperthyroidism is well known both through radiologic observations and the occurrence of diarrhea in severe cases. The same phenomenon was also observed experimentally (19). The opposite, namely, abnormally sluggish intestinal peristalsis, is characteristic of myxedema, in which there is also a markedly diminished fecal output of calcium. In our rats injected with thyroxin, a tendency to diarrhea was also noted. It was brought out particularly when somewhat irritating substances such as xylose, phlorizin, or oleic acid were administered (11). In the experiment where a mixture of oleic acid and phlorizin had to be given, all hyperthyroid rats developed diarrhea and we were forced to control this tendency with morphine before administering the mixture. Under similar circumstances, no normal rats developed diarrhea.

Whether overeating or hyperperistalsis has a greater influence on fecal excretion of calcium is a difficult problem to solve. On the one hand, we obtained more decisive experimental results by producing increased peristalsis. On the other hand, a greater volume of food would not only cause the diffusion of more calcium from the blood but would also stimulate peristalsis.

If we accept hyperperistalsis and overeating as the chief causes of increased fecal output of calcium in hyperthyroidism, we are able to account for several clinical and experimental observations heretofore unexplained: (1) Our theory accounts for the loss of calcium through the bowel in hyperthyroidism in the absence of hypercalcemia. It explains why hyperthyroidism is the only disease characterized by a negative calcium balance in which loss of calcium in the feces plays a prominent part (6). (3) It explains the occasional absence of increased fecal calcium in hyperthyroidism $(7,8)$ by the fact that this is not a primary feature of the disease but depends on the presence of increased intestinal peristalsis and overeating, in themselves secondary manifestations of hyperthyroidism that may occasionally be absent. (4) In conjunction with the mechanism of intestinal absorption discussed above, our theory accounts for the absence of fecal loss of calcium in hyperparathyroidism and other diseases characterized by hypercalcemia and a negative calcium balance but lacking increased intestinal peristalsis and overeating. In these conditions, an abnormally high level of calcium in the blood presumably leads to increased diffusion of calcium into the small intestine, but later this excess of calcium is re-absorbed in the colon with little or no resultant loss of calcium in the feces. (5) It probably accounts for the finding of Pugsley (20) that a negative calcium balance due to increased fecal output of calcium can be produced experimentally in rats by oral administration of very large doses of dinitrophenol. While preparing rats for an absorption experiment with administration of dinitrophenol (11) by stomach-tube twice a day, in doses much smaller than the ones used by Pugsley, it was observed that many of our animals developed spontaneous diarrhea and could not be used for the intended purpose. The probability that hyperperistalsis rather than stimulation of metabolism was responsible for the increased fecal excretion of calcium obtained by Pugsley is enhanced by his inability to produce a rise in fecal calcium with subcutaneous or intraperitoneal injections of dinitrophenol which would obviate local irritation of the digestive tract. It is also significant that Robbins (21) found the excretion of calcium and phosphorus to be normal in patients receiving clinical doses of dinitrophenol that raised the basal metabolic rate to 37 per cent plus but presumably were not large enough to cause intestinal irritation. Our theory that intestinal hyperperistalsis plays an important part in the fecal loss of calcium in hyperthyroidism is supported by a recent article of Meulengracht (22) in which he describes the occurrence of osteomalacia of the spine due to daily use of cathartics over a long period of time.

In view of our discovery that increased intestinal peristalsis and overeating play an important part in the increase of fecal excretion of calcium in hyperthyroidism, it will be interesting to see whether increased elimination of calcium in the urine, which takes place in this condition in spite of a normal or practically normal calcium level 
of the blood, can also be explained on the basis of an acceleration of the urinary flow, an increase in the intake of water, or both. Experiments to test these possibilities are under way.

Our data on the calcium exchange of the intestine do not contradict the extensive investigations of calcium metabolism in hyperthyroidism performed by Aub and his co-workers, which led to the conclusion that the source of the calcium that is being lost in this condition is the tertiary calcium phosphate from the bones. But they furnish an explanation of the mechanism by which the loss of calcium in the feces takes place, creating the necessity of drawing on the calcium reserves of the skeleton. Our experiments are also of help in reconciling the often contradictory data obtained when some workers study the calcium metabolism in hyperthyroidism under conditions of a low calcium intake while others allow an adequate dietary calcium.

\section{SUM MARY}

1. Administration of thyroxin or of subpurgative doses of castor oil or of cascara to rats approximately doubled the fecal excretion of calcium.

2. Restriction of the food intake or administration of morphine markedly decreased the fecal output of calcium in hyperthyroid rats.

3. Increased permeability of the intestinal mucosa, active excretion of calcium, and increased absorption of food elements enjoying preferential intestinal absorption were ruled out as factors causing loss of calcium through the feces in hyperthyroidism.

4. From these findings it is concluded that hyperperistalsis and overeating are the chief causes of increased fecal output of calcium in hyperthyroid rats maintained on a calcium-free diet.

5. The proposed theory of increased fecal excretion of calcium in hyperthyroidism accounts for several heretofore unexplained clinical and experimental observations in conditions associated with a negative calcium balance.

6. There is no appreciable change in calcium absorption in hyperthyroidism.

\section{BIBLIOGRAPHY}

1. Parhon, M., L'influence de la thyroide sur le métabolisme du calcium. Compt. Rend. Soc. de Biol., $1912,72,620$.
2. Aub, J. C., Bauer, W., Heath, C., and Ropes, M., Studies of calcium and phosphorus metabolism. III. Effects of thyroid hormone and thyroid disease. J. Clin. Invest., 1929, 7, 97.

3. Pugsley, L. I., and Anderson, E. M., Effect of desiccated thyroid, irradiated ergosterol and ammonium chloride on excretion of calcium in rats. Biochem. J., 1934, 28, 754.

4. Pugsley, L. I., and Anderson, E. M., Effect of administration of calciferol on increased calcium excretion induced by thyroxine. Biochem. J., 1934, 28, 1313.

5. Cope, O., and Donaldson, G. A., Relation of thyroid and parathyroid glands to calcium and phosphorus metabolism. J. Clin. Invest., 1937, 16, 329.

6. Aub, J. C., Calcium and phosphorus metabolism. Harvey Lectures, series XXIV, 1928-1929, p. 151.

7. Hansman, F. S., and Wilson, F. H., Calcium and phosphorus metabolism in diseases of the thyroparathyroid apparatus. I. Calcium, phosphorus and total metabolism in hyperthyroidism and part played by parathyroid glands. M. J. Australia, 1934, 1, 37.

8. Hansman, F. S., and Fraser, W. A., Calcium and phosphorus metabolism in diseases of thyro-parathyroid apparatus. II. Calcium and phosphorus balance (a) following therapeutic radiation of hyperplastic thyroid gland, and (b) in hyperthyroidic patients treated with iodine. J. Clin. Invest.. 1938, 17, 543.

9. Kummer, R. H., Recherches sur le métabolisme mineral dans la maladie de Basedow. Rev. méd. de la Suisse Rom., 1917, 37, 439.

10. Albright, F., Bauer, W., and Aub, J. C., Studies of calcium and phosphorus metabolism. VIII. Influence of thyroid gland and parathyroid hormone upon total acid-base metabolism. J. Clin. Invest., 1931, 10, 187.

11. Althausen, T. L., and Stockholm, M. Influence of thyroid gland on absorption in digestive tract. Am. J. Physiol., 1938, 123, 577.

12. Petersen, W. F., and Levinson, S. A., Skin reactions, blood chemistry, and physical status of "normal" men and of clinical patients. Arch. Path., 1930, 9, 151.

13. Guassardo, G., and Peola, F., Influenza di alcuni ormoni sull'assorbimento intestinale del $\mathrm{Ca}_{2}$ K. Pathologia, 1930, 22, 455.

14. Cohn, W. E., and Greenberg, D. M., Studies in mineral metabolism with aid of artificial radioactive isotopes. I. Absorption, distribution, and excretion of phosphorus. J. Biol. Chem., 1938, 123, 185.

15. Benedict, F. A., and Macleod, F., Heat production of albino rat. I. Technique, activity control, and influence of fasting. J. Nutrition, 1929, 1, 343.

16. Verzár, F., and McDougal, E. J., Absorption from the Intestine. Longmans, Green and Co., London, New York and Toronto, 1936.

17. Welch, C. S., Wakefield, E. G., and Adams, M., Func- 
tions of large intestine of man in absorption and excretion. Arch. Int. Med., 1936, 58, 1095.

18. Johnson, R. M., Absorption and excretion of calcium and phosphorus in three patients with colostomy and ileostomy. J. Clin. Invest., 1937, 16, 223.

19. Morrison, S., and Feldman, M., An experimental study of the effect of the thyroid on the motility of the gastro-intestinal tract. Am. J. Digest. Dis., 1939, $6,549$.
20. Pugsley, L. I., Effect of 2:4-dinitrophenol upon calcium, creatine and creatinine excretion in rat. Biochem. J., 1935, 29, 2247.

21. Robbins, C. L., Effect of dinitrophenol on calcium and phosphorus metabolism. J. Nutrition, 1935, 10, 187.

22. Meulengracht, E., Osteomalacia of spine following abuse of laxatives. Lancet, 1938, 2, 774. 